\title{
RESENSI FILM DOKUMENTER KING GIMP MIMPI DALAM KETERBATASAN \\ MEDIA VIDEO SEBAGAI SARANA PENDIDIKAN KEDOKTERAN
}

\author{
Jenny Maria, Elisabeth Rukmini \\ Fakultas Kedokteran Universitas Katolik Indonesia Atma Jaya \\ Jakarta
}

Judul Film : King Gimp ${ }^{1}$

Sutradara : William A. Whiteford

Producer : Susan Hannah Hadary

William A. Whiteford

Editor : Geof Bartz

Penulis : Daniel Keplinger

Durasi : 39 menit 50 detik

Produksi : University of Maryland School of Medicine dan Tapestry International Production, 1999

Most people think 'gimp' means someone with a lame walk, but 'gimp' also means a 'fighting spirit'. (Dan Keplinger, King Gimp)

\section{LATAR BELAKANG}

King Gimp sebagai film dokumenter sungguh sarat makna untuk menjadi bahan pembelajaran di fakultas kedokteran. Film ini berhasil menyuguhkan kerja keras sutradara Whiteford dan produser Hadary menyajikan semacam visualisasi riset longitudinal tentang satu subyek bernama Dan Keplinger yang menyandang cerebral palsy. Film berdurasi pendek ini memenangi Oscar pada tahun 1999 dalam kategori Academy Award for Best Documentary Short Subject, Peabody Award. Film ini dapat menjadi trigger diskusi kelompok pada beberapa mata kajian seperti: pengantar ilmu kedokteran, humaniora, ilmu kesehatan masyarakat, kedokteran paliatif, ilmu mental dan perilaku. Film ini juga dapat digunakan secara berulang untuk melihat respon mahasiswa kedokteran pada tingkat-tingkat tertentu. Di awal karir kemahasiswaannya

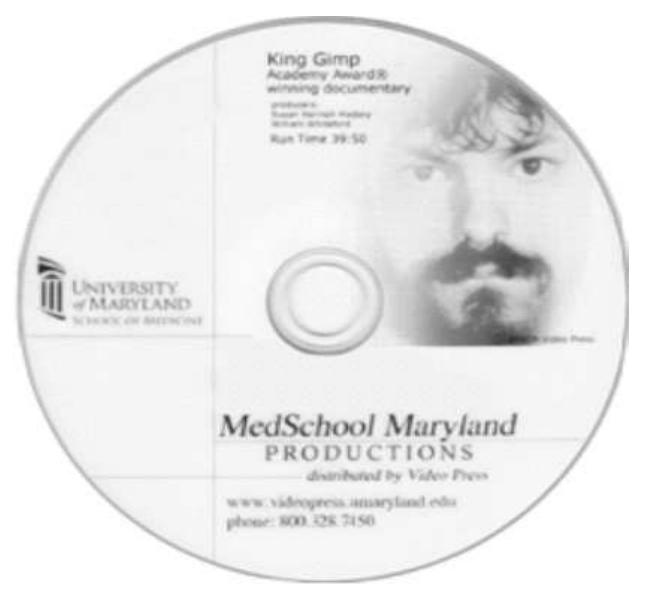

misalnya, film ini dapat digunakan sebagai pemicu diskusi tentang proses penghargaan terhadap diri sendiri mempengaruhi perkembangan pribadi apapun kekurangan diri termasuk di dalamnya aspek layanan kesehatan dan kedokteran secara umum. Dalam kajian humaniora di tahun pertama hingga kedua pendidikan kedokteran, film ini dapat menjadi pemicu diskusi mengenai aspek etik dan dukungan orang-orang terdekat dalam penghargaan terhadap karya dan hak hidup seseorang apapun kondisinya. Pada menjelang tingkat akhir pendidikan kedokteran, dalam mata kajian mental dan perilaku barangkali menarik untuk menjadikan film ini bagian pembahasan perkembangan mental seseorang dalam kondisi fisik yang terbatas. Pemaknaan akan film ini dapat menjadi tugas penulisan serta diskusi yang menarik.

Korespondensi: jennydharmawan@gmail.com, elisabeth.rukmini@gmail.com 


\section{DESKRIPSI}

Setiap orang pasti memiliki mimpi dalam diri mereka. Mimpi tak mengenal umur dan fisik seseorang. Asalkan ada niat dan kemauan, semua dapat digapai. Hal itulah yang tergambarkan dalam diri Daniel Keplinger (Dan). Dan adalah seorang anak yang lahir dengan Cerebal Palsy. Seluruh semangat juang dan rintangan yang dihadapi oleh Dan dalam perjalanan hidupnya, sejak berumur 12 tahun hingga ia lulus dari universitas, dituangkan dalam film dokumenter yang disutradai oleh William A. Whiteford.

"Most people think 'gimp' means someone with a lame walk, but 'gimp' also means a 'fighting spirit'” inilah prinsip yang dipegang oleh Dan. Film dokumenter yang diperani oleh Dan sendiri menceritakan perjalanan hidupnya sebagai anak berkebutuhan khusus yang penuh tantangan dan kesulitan serta kebahagiaan. Saat Dan berusia 6 tahun, kedua orang tuanya bercerai. Hal ini dikarenakan ayahnya tidak dapat menerima kehadirannya. Saat ia beranjak dewasa, ia masih memerlukan pertolongan orang lain untuk membawanya dari satu tempat ke tempat yang lain karena ia sulit mengontrol tubuhnya sendiri. Namun hal ini tidak membuat ibunya memberikan perlakuan istimewa terhadapnya. Ibunya memperlakukan ia seperti kebanyakan anak normal.

Pada usia 12 tahun, Dan masuk dalam Ridge School, sekolah bagi anak-anak berkebutuhan khusus. Di Ridge School, anak-anak dapat bertahan hingga mereka berusia 21 tahun. Namun Dan tidak bertahan lama di sekolah tersebut. Tak lama berselang setelah kematian sahabat karibnya, Pete, yang meninggal karena muscular dystrophy, Dan keluar dari Ridge School. Ibu Dan, memasukkannya dalam suatu sekolah umum saat usia Dan 14 tahun. Kendala nyata jelas di depan mata Dan saat harus belajar bersama anak-anak normal lainnya. Ia mengalami berbagai hambatan, mulai dari cara belajar hingga membuat PR. Ia juga sulit dalam menjalin hubungan sosial dengan teman-teman lainnya karena memiliki jadwal kegiatan pribadi dengan bantuan orang lain yang berbeda dengan siswa di sekolah.

Di samping kendala yang menyulitkan itu, Dan menemukan belahan jiwanya, seni. Seni lukis menjadi jendela bagi Dan untuk mengekspresikan dirinya. Dalam lukis, Dan bebas mengintrepretasikan apa saja tanpa memerlukan bantuan orang lain untuk mengintrepertasikan baginya. Ia merasa menemukan makna yang selama ini ia cari, hal yang dapat membuat ia menjadi bersemangat dalam menjalani hidup ini meski ada keterbatasan fisik. Saat melukis, Dan merasakan suatu perasaan yang damai dan tentram. Sapuan demi sapuan ia torehkan diatas kanvas mengenai cerita yang ingin ia sampaikan. Setiap dari karyanya memiliki suatu karakteristik yang menggambarkan dirinya.

Kehidupan Dan pun terus berlanjut hingga ia melanjutkan pendidikannya di tingkat universitas. Pada usia 20 tahun, Dan terdaftar menjadi salah satu mahasiswa di Towson University. Kehidupan perkuliahan pun tidaklah mudah bagi Dan. Ia melakukan segalanya sendiri. Di sana ia bertemu dengan Stuart Stein yang membangkitkan gairah melukisnya. Semua hal yang ia perjuangkan tidaklah sia-sia. Dan berhasil menyelesaikan studinya dan membuktikan bahwa orang yang berkebutuhan khusus juga dapat menyelesaikan studinya dengan baik.

Semua keyakinan dan keinginan Dan untuk terus berjuang tidak lepas dari dukungan yang diberikan oleh ibunya, Linda Ritter, serta teman dekatnya, Laura Moure yang terus menerus mendampingi Dan. Dalam dirinya yang penuh keterbatasan, Dan dengan dibantu kursi rodanya dan alat yang dipasang pada kepalanya berhasil mendobrak segala keterbatasan yang menghalangi dirinya dalam berekspresi. Ia berhasil mengesampingkan berbagai pikiran orang yang meremehkan orang berkebutuhan khusus dengan menampilkan karya-karya seninya pada sebuah galeri seni.

\section{ANALISIS}

Film dokumenter telah digunakan secara luas sebagai sumber pembelajaran dalam pendidikan kedokteran dan profesi bidang kesehatan. ${ }^{(2-4)}$ Sumber semacam ini digunakan secara mandiri ataupun sebagai sarana bagi dosen untuk mendiskusikan kasus atau masalah kedokteran dan kesehatan. Terdapat dua teori pendidikan yang berkaitan dengan pembelajaran melalui film dokumenter ini, yaitu prinsip-prinsip pembelajaran orang dewasa dan pembelajaran mandiri. Kedua teori ini erat hubungannya dengan aplikasi pembelajaran kedokteran melalui audio visual. 
Prinsip-prinsip pembelajaran orang dewasa membahas tentang kerangka berpikir para orang dewasa dalam belajar. Andragogy atau karakteristik belajar orang dewasa memaparkan bahwa dalam pembelajaran ini seseorang menjadi pengontrol dirinya sendiri dalam menjalankan setiap keputusan dan mandiri. Setiap pribadi dapat menentukan apa yang perlu dipelajari dan apa yang menjadi kebutuhan mereka. Dalam perjalanannya, seseorang yang dewasa menempatkan seluruh pengalaman hidupnya sebagai wadah untuk belajar. Peran sosial seseorang juga berpengaruh pada pola berpikir seseorang.

Seorang dewasa mengutamakan problem solving dalam pembelajaran sehingga dapat diaplikasikan dalam kehidupan sehari-hari. ${ }^{(5-7)}$ Seorang dewasa juga lebih terpacu dalam belajar bila didasari motivasi dari dalam diri sendiri ketimbang motivasi dari luar. ${ }^{(8-10)} \mathrm{Hal}$ ini menyangkut apa yang ingin dicapai secara personal.

Pembelajaran orang dewasa tentu berbeda dengan pembelajaran pada anak-anak. Seorang dewasa memiliki tanggung jawab atas setiap keputusan yang ia ambil dalam hidupnya. Biasanya seorang dewasa belajar dan menangani berbagai kasus yang spesifik tidak seperti anak-anak yang mempelajari berbagai hal secara umum. Setiap keinginan pembelajaran dari orang dewasa berawal dari keinginan diri sendiri, mengarahkan serta mengambil tindakan sendiri, dan memaknai hidup sebagai suatu pengalaman yang menjadi sumber pembelajaran. Seorang dewasa juga dapat menentukan mana yang penting dan mana yang kurang penting. Ia akan cenderung meninggalakan hal-hal yang dirasa kurang penting dan memaksimalkan apa yang penting bagi dirinya. Film dokumenter King Gimp mengisi pemaknaan pengalaman ini bagi pemirsanya. Kegigihan dan ketangguhan Dan dalam menjalani hidup sangat patut diberikan apresiasi. Seseorang yang penuh dengan keterbatasan memiliki daya juang yang tinggi dalam menggapai apa yang ia inginkan dalam hidup ini. Selayaknya orang-orang yang memiliki tubuh yang sehat tanpa keterbatasan memiliki yang tak kalah dengan Dan.Peran sosial juga dapat dimaknai dari King Gimp via tokoh-tokoh nyata seperti Ibu dari Dan, teman sekaligus mentor Dan, teman-teman dalam kelompok sekolah dan kuliahnya serta orang-orang yang mendukungnya dalam karya seni rupanya.
Dalam praktik di kelas, proses pemaknaan tersebut dapat ditugaskan sebagai bentuk refleksi mandiri mahasiswa atau dapat dibahas bersama dari sudut pandang peranperan yang ada dalam King Gimp. Tugas yang pertama dapat diberikan sebagai bentuk refleksi mandiri tentu disertai pertanyaan-pertanyaan yang menggiring pada pemaknaan pengalaman. Tugas kedua di dalam kelas bisa mengawali atau menjadi debriefing setelah proses menonton ataupun setelah mahasiswa mengerjakan tugas refleksi mereka. Penting kiranya untuk menyusun penugasan tersebut sebagai rancangan pembelajaran sebelum memutuskan menggunakan materi King Gimp di kelas. Film ini dapat digunakan pada tahun pertama, kedua ataupun ketiga mahasiswa kedokteran dan profesi kesehatan dengan tinjauan pandang pemaknaan pengalaman yang beragam. Pada tahun pertama, pemaknaan sosok utama berikut peran sosialnya di dalam film ini barangkali akan paling kentara dan mudah dipahami, artinya proses hidup Dan sendiri yang diberi makna. Pada tahun ketiga, ketika mahasiswa sudah lebih dewasa, film ini dapat didiskusikan dalam ranah pemaknaan pengalaman sosial melalui peran-peran sosial di dalamnya sambil memasukkan peran pendukung regulasi negara untuk para penyandang disabilitas. Film dokumenter ini tak hanya berisi berbagai nilai kehidupan dan apresiasi bagi orang-orang yang memiliki kemauan yang sangat besar untuk terus berjuang bertahan hidup dengan keterbatasan fisik. Film ini juga menggambarkan aspek layanan kesehatan dan kedokteran yang dihidupi dalam lingkup personal hingga komunitasnya. Tak hanya itu, film ini juga menampilkan kepiawaian subyek-subyek terkait di dalamnya melakukan riset longitudinal.

Aspek teoritik kedua dari penggunaan media dokumenter dalam pendidikan adalah proses belajar mandiri. Pembelajaran mandiri atau lifelong learning adalah pembelajaran yang perlu dilakukan pada edukasi profesional misalnya pada kedokteran dan profesi kesehatan. Pembelajaran ini mengutamakan adanya aktualisasi diri dan tanggung jawab pribadi serta kebebasan dalam memilih dan melakukan tindakan. Belajar mandiri bukanlah berarti melepaskan suatu materi secara bebas kepada mahasiswa. Dalam proses belajar mandiri, mahasiswa tetap perlu berada pada ranah pembimbingan dari fasilitator atau instuktur. ${ }^{(11,12)}$ Syarat 
pendampingan ini juga memiliki metode pembelajaran yang terorganisir melalui adanya instruksi yang menjadi patokan seseorang dalam belajar.

Belajar mandiri mengandalkan kebebasan pribadi dalam menentukan sumber belajarnya, manajemen pribadi dalam belajar dan kesadaran atau kemauan untuk belajar. ${ }^{(13)}$ Siswa menentukan dengan bebas sumber belajarnya, hal ini tampaknya kontradiktif dengan konsep di atas bahwa instruksi perlu diberikan oleh pengajar. Kembali kepada konsep pembelajaran bagi orang dewasa, sumber belajar tidak dapat diberikan satu saja, ada banyak alternatif, termasuk di dalamnya sumbersumber yang pada akhirnya secara bebas diputuskan oleh pembelajar sebagai sumber yang paling tepat bagi dirinya.

Oleh karenanya, peran pengajar adalah memberikan alternatif. Jika film dokumenter diandaikan sebagai salah satu alternatif sumber belajar yang diberikan dengan pembimbingan, maka pengajar juga perlu memberikan alternatif pendamping sehingga siswa dapat memilih dan memperkaya sumber-sumbernya melalui belajar mandiri. ${ }^{(13)}$ Yang kedua, belajar mandiri mengandaikan mahasiswa sebagai pribadi dewasa sanggup dengan kebebasannya mengatur sendiri waktu dan masalah (management of time and conflict) dalam belajar. Sekali lagi, fasilitasi dari dosen melalui penugasan dan konsultasi mendorong pengaturan yang efektif. Tenggat waktu penugasan, target capaian yang harus dipelajari dalam penugasan, akan mendorong mahasiswa memenuhi tujuan pembelajaran. Artinya, pemberian media dokumenter perlu menjamin ketercapaian mahasiswa terhadap media itu. Media secara praktis perlu ada di tempat yang dapat dicapai misalnya di perpustakaan, sebagai bahan ajar yang sifatnya tandon, untuk dapat ditonton bersama atau berkali-kali dalam ruang visual milik kampus.

Konsep belajar mandiri mengejawantahkan teori pedagogik pembelajaran, diantaranya teori kognitif, teori pembelajaran sosial, humaniora dan tentu saja konstruktivisme. Semua ini berkaitan dengan kebebasan seseorang dalam belajar dan kesadaran seseorang akan kebutuhan belajarnya.

Terdapat beberapa faktor yang mempengaruhi seseorang dalam melaksanakan pembelajaran mandiri. Pembelajar yang melihat dirinya sebagai orang yang kompeten akan lebih terarah dan mandiri dalam belajar. Terkadang instruksi yang menjadi patokan seseorang dalam belajar membawa seseorang menjadi tidak memiliki kebebasan dalam mengarahkan dirinya sendiri dalam pembelajaran mandiri ini. Situasi dan kondisi di sekitar pembelajar juga mempengaruhi seseorang dalam belajar. ${ }^{(8,14)}$ Apa yang ia pelajari biasanya adalah hal yang akan ia praktikkan dalam lingkungan atau profesi yang ia jalani. Dalam pembelajaran juga dibutuhkan diskusi untuk memahami persepsi dan asumsi sehingga pola pikir seseorang menjadi lebih terbuka dan terarah. Evaluasi dari diri sendiri maupun dari orang lain juga merupakan poin yang penting dalam kesuksesan pembelajaran mandiri. Meminta pendapat orang lain berkaitan dengan kinerja seseorang merupakan salah satu cara yang baik untuk mengetahui apakah hasil pembelajaran orang tersebut telah memenuhi target.

Dalam praktiknya seseorang membutuhkan lingkungan yang kondusif, di mana ia dapat merasa nyaman untuk bertanya dan menemukan jawaban yang ia cari. Dalam pembelajaran yang bermakna seseorang membutuhkan pemahaman yang mendalam sehingga ia harus mencari berbagai informasi untuk mendapatkan apa yang perlu ia pahami. ${ }^{(15,16)} \mathrm{Hal}$ ini tentu erat kaitannya dengan pembelajaran mandiri. Seseorang menentukan apa saja yang perlu ia pahami sesuai dengan apa yang ia inginkan dan perlukan.

Praktik pembelajaran mandiri ini penulis rasakan dalam tugas pembuatan resensi film ini. Dosen memberikan tugas membuat resensi film yang pada akhirnya merujuk mahasiswa untuk melakukan pembelajaran mandiri. Sang mahasiswa melakukan pembelajaran mandiri dengan menonton film tersebut secara pribadi dan merefleksikan nilai-nilai yang terkandung dalam film tersebut dalam wujud resensi film. Tentu dalam menuliskan resensi film tersebut sang mahasiswa tidak terpatok namun memiliki kehendak bebas dalam menguraikan berbagai nilai yang terkandung dalam film King Gimp ini. Menonton film merupakan salah satu cara bagi mahasiswa kedokteran untuk mengelaborasi dan merefleksikan diri sendiri. Dari hal yang sederhana ini sang mahasiswa dapat memperkaya diri dan menambah pengetahuan bagi dirinya. 
Dalam film dokumenter ini, bagi beberapa orang akan mengalami kesulitan untuk memahami apa yang dikatakan oleh Dan bila tidak ada subtitle. Sebagai film dokumenter yang didistribusikan ke berbagai negara, latar belakang lokasi perlu lebih digambarkan dengan detil. Namun diluar semua itu, sinematografi yang disuguhkan dalam film ini sangatlah apik dan membuat setiap orang yang menonton dapat terhanyut dalam cerita

\section{KESIMPULAN}

Film dokumenter yang telah meraih Penghargaan Oscar ini patut ditonton oleh berbagai kalangan, terutama oleh mahasiswa kedokteran dan profesi kesehatan sebagai salah satu bahan ajar. Materi dalam film ini dapat dikaitkan dengan aspek kedokteran umum ataupun dengan hubungan sosial dan kesehatan masyarakat. Film ini tersedia dalam versi untuk siswa sekolah umum. Versi bagi siswa ini memotong kata-kata yang dipandang vulgar atau berkaitan dengan seksualitas. Dengan demikian, film King Gimp versi siswa menjadi layak ditonton oleh segala usia.

\section{DAFTAR PUSTAKA}

1. Whiteford W, Hadary SH. King Gimp. 2013.

2. Balslev T, De Grave WS, Muijtjens AMM, Scherpbier AJJA. Comparison of text and video cases in a postgraduate problem-based learning format. Med Educ. 2005 Nov 1;39(11):1086-92.

3. Briscoe MH, Byrne A, Hicks B, Care DA, Williams $\mathrm{PA}$, Jones $\mathrm{G}$. Interactive video teaching using a home microcomputer. Med Educ. 1987 Jan 1;21(1):15-7.

4. De Leng B, Dolmans D, Van de Wiel M, Muijtjens A, Van Der Vleuten C. How video cases should be used as authentic stimuli in problem-based medical education. Med Educ. 2007 Feb 1;41(2):181-8.

5. Van der Veken J, Martinde Maeseneer, JanSchuwirth, LambertDerese, Anselm. Impact on knowledge acquisition of the transition from a conventional to an integrated contextual medical curriculum. Med Educ. 2009 Jul;43(7):704-13.
6. Kolb AY, Kolb DA. Kolb, A. Y. (2005). The Kolb learning style inventory-version 3.12005 technical specifications. Boston, MA: Hay Resource Direct. Hay Resources Direct, Boston, MA.; 2005.

7. Newble DI, Entwistle NJ. Learning styles and approaches: implications for medical education. Med Educ. 1986 May 1;20(3):162-75.

8. Dolmans DH, Schmidt HG. What do we know about cognitive and motivational effects of small group tutorials in problem-based learning? Adv Health Sci Educ Theory Pract. 2006;11:321-36.

9. Klein HJ, Noe RA, Wang C. Motivation to learn and course outcomes: the impact of delivery mode, learning goal, orientation, and perceived barriers and enablers. Pers Psychol. 2006 Autumn;59(3):665702.

10. Glynn SM, Duit R. Learning science meaningfully: constructing conceptual models. In: Glynn SM, Duit R, editors. Mahwah, N.J.: L. Erlbaum Associates; 1995. p. 3-33.

11. Miflin, Campbell, Price. A conceptual framework to guide the development of self-directed, lifelong learning in problem-based medical curricula. Med Educ. 2000 Apr 1;34(4):299-306.

12. Hammond M, Collins R. Self-directed Learning to Educate Medical Educators. Part 1: How do we use self-directed learning? Med Teach. 1987 Jan 1;9(3):253-60.

13. Taylor DCM, Hamdy H. Adult learning theories: Implications for learning and teaching in medical education: AMEE Guide No. 83. Med Teach. 2013 Sep 4;35(11):e1561-e1572.

14. Berkel HJM van, Schmidt HG. Motivation to commit oneself as a determinant of achievement in problembased learning. High Educ. 2000;40(2):231-42.

15. Delva D, Sargeant J, Miller S, Holland J, Alexiadis Brown P, Leblanc C, et al. Encouraging residents to seek feedback. Med Teach. 2013 Jul 12;35(12): e1625-e1631.

16. Armstrong GW, Wald HS. Fostering reflective capacity with interactive reflective writing in medical education: Using formal analytic frameworks to guide formative feedback to students' reflective writing. Med Teach. 2013 Jan 25;35(3):258-258. 